\author{
Asian Economic and Financial Review \\ $\operatorname{ISSN}(e): \quad 2222-6737$ \\ $\operatorname{ISSN}(p): \quad 2305-2147$ \\ DOI: $10.18488 /$ journal.aefr.2021.115.396.405 \\ Vol. 11, No. 5, 396-405. \\ (C) 2021 AESS Publications. All Rights Reserved. \\ URL: www.aessweb.com \\ check for
}

\title{
RELATIONSHIP BETWEEN CENTRAL BANK INDEPENDENCE AND FOREIGN DIRECT INVESTMENT INFLOWS
}

\section{Oscar Mukhametov}

\author{
Financial Research Institute of the Ministry of Finance of the Russian \\ Federation, Moscow, Russian Federation. \\ Email:omukhametov@nifi.ru Tel:+7(926)419-94-23
}

(1) Check for updates
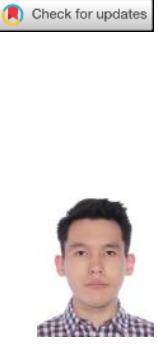

ABSTRACT
Article History

Received: 4. February 2021 Revised: 8 March 2021

Accepted: 6 April 2021

Published: 28 April 2021

\section{Keywords}

Foreign direct investment Central bank independence Panel regression

Institutional quality

Financial development

JEL Classification: C33; E58; F21.

\begin{abstract}
The principal objective of this paper is to scrutinize the relationship between central bank independence and foreign direct investment (FDI) inflows. The relevance of this goal is based on the results of recent studies, which indicate that the inflow of direct investment into the economy depends not only on its indicators of economic development, but also on the quality of the institutional environment. The study used a sample of 180 countries covering the period from 1970 to 2012 to model the relationship between the level of central bank independence and inflows of foreign direct investment. The primary method used in the study is linear panel regression with country-specific fixed effects. The results of the econometric modeling demonstrate that an increase in the central bank independence index has a statistically significant positive effect on the inflow of foreign investment. This result can serve as the basis for monetary policy reforms, particularly in developing countries since the expansion of the central bank's independence can become a factor in increasing the investment attractiveness of the economy.
\end{abstract}

Contribution/Originality: This study is one of very few studies which have investigated the effects of central bank independence on the investment attractiveness of an economy.

\section{INTRODUCTION}

This article explores the relationship between central bank independence and FDI inflows. FDI is one of the key drivers of economic growth, helping to expand the productive capacity of an economy through the exchange of technology. The inflow of FDI statistically and significantly depends on the macroeconomic stability in the economy (low and stable inflation, a balanced budget and an adequate level of public debt), its trade openness, the size of the domestic market and the rate of economic growth. In addition, the institutional environment also impacts the investment attractiveness of an economy.

This study suggests that central bank independence can influence inflows of FDI. Thus, the research question in this article is formulated as follows: What effect does the level of central bank independence exert on FDI inflows into the economy? Central bank independence is associated with lower and more stable inflation and reduces the uncertainty of economic agents, thereby contributing to macroeconomic stability and, as a result, the inflow of FDI.

To test this hypothesis, a linear panel regression with fixed effects was employed in the study. The volume of FDI inflow was used as a dependent variable, and the list of independent variables included indicators of the real, fiscal, external and monetary sectors, as well as indicators of the quality of institutions. The sample included 180 
countries for the period from 1970 to 2012. The findings suggest that higher levels of central bank independence are associated with higher inflows of FDI.

The article proposes to consider, first, lower and more stable inflation, and second, financial development as the key channel of influence of the central bank's independence on the inflow of FDI. In particular, a lower and more stable inflation helps to reduce the uncertainty of economic agents and keeps real interest rates at a lower level, thus making it possible to increase the investment attractiveness of the economy. At the same time, financial development presupposes a more developed system of lending, as well as expanding agents' access to financial services, which also has a positive impact on the inflow of FDI.

Thus, this study shows that one of the directions of reform, particularly in developing countries, may be to increase the independence of the central bank. Such transformations will have a positive macroeconomic effect contributing to low and stable inflation, and less volatile economic growth. The reduced uncertainty will help increase the investment attractiveness of the economy.

The article is structured as follows. Section 1 examines the key determinants of FDI and its role in promoting economic growth; Section 2 describes the concept of central bank independence as well as its macroeconomic effects; Section 3 provides information on the data used and describes the research methodology; Section 4 presents the results of econometric modelling; Section 5 contains the empirical analysis; and in the conclusion, the possible channels of influence of central bank independence on FDI inflows are described, which may become the subject of future research.

\section{FOREIGN DIRECT INVESTMENT AND THEIR DETERMINANTS}

The research and political interest in FDI is primarily due to its role in accelerating economic growth (Iamsiraroj, 2016; Pegkas, 2015). The use of FDI as a means of increasing economic growth is most relevant for developing countries, owing to their limited resources to support the economy. In addition, FDI accelerates economic growth through new technologies that expand the productive frontiers of the economy (Yao \& Zhang, 2001).

Because the inflow of FDI has a number of positive effects, a significant part of economic research is devoted to identifying factors that contribute to the inflow of FDI. A review of these studies has ascertained several key determinants of FDI inflows.

The first group of factors includes variables that describe the state of the real sector of the economy. First, it is the size of the market; the larger economies with significant demand attract higher FDI (Bevan \& Estrin, 2004; Vijayakumar, Sridharan, \& Rao, 2010). Second is the rate of economic growth, which is also positively associated with the attractiveness of the economy for investment by multinational companies (Iamsiraroj, 2016). Third, FDI inflows are likely to be higher in countries with lower and more stable inflation rates (Kok \& Ersoy, 2009; Rogoff \& Reinhart, 2003; Sayek, 2009).

The second group of factors covers indicators of the fiscal sector of the economy. In particular, FDI inflows are higher in countries that have smaller fiscal deficits (Mohanty \& Behera, 2017) and lower levels of government debt (Kok \& Ersoy, 2009). Thus, a balanced fiscal policy enhances investor confidence as it supports the country's solvency and expands the government's ability to support the economy in situations of adverse shocks.

The third group of factors concerns the state of the monetary sector of the economy. For example, some studies have found a relationship between the interest rate cycle and the dynamics of FDI inflows (Mohanty \& Behera, 2017). The lower interest rates boost lending and aggregate demand, which can increase the profitability of projects.

The fourth group of factors comprises the variables of the external sector of the economy. The most significant predictor of FDI inflows is trade openness; investors find countries with fewer trade restrictions and a higher share of imports and exports in GDP more attractive (Iamsiraroj, 2016; Kinuthia \& Murshed, 2015). In addition, Kaur, 
Yadav, \& Gautam (2012) found a relationship between FDI and the current account balance; a current account surplus contributes to higher investment inflows.

The fifth group of factors covers the variables that characterize the institutional environment of the economy. A weaker level of institutional development (e.g., a high level of corruption, political instability and ineffective regulation) limits the effectiveness of the market mechanism, which reduces the potential profitability of the project and, accordingly, leads to a decrease in the inflow of FDI (Blonigen, 2005). Ali, Fiess, \& MacDonald (2010) also pointed to a significant relationship between the quality of institutions and FDI, highlighting the particular role of protecting property rights.

Thus, modern studies emphasize a wide range of factors affecting the inflow of FDI into the economy. The size of the economy and its growth prospects, as well as the ability of the authorities to ensure macroeconomic stability in the form of a balanced budget, a reasonable level of public debt and low inflation, are crucial in terms of investment attractiveness. Furthermore, the inflow of FDI is closely related to the level of interest rates to the economy and the country's trade openness. At the same time, an important observation is the positive relationship between the quality of institutions and the inflow of FDI. In this context, the hypothesis regarding the possible impact of central bank independence becomes more tangible and reasonable.

\section{CENTRAL BANK INDEPENDENCE CONCEPT: SIGNIFICANCE AND MEASUREMENT ISSUES}

Initially, central bank independence was regarded a prerequisite for overcoming dynamic monetary policy failure in academic literature. In general, delegating monetary policy to a more conservative central banker reduces the deviation of actual inflation from the socially optimal level (Fischer, 1995). At the same time, the independence of the central bank can be organized within the framework of the principal-agent model, in which the central banker bears the costs of deviating inflation from the target (Fischer, 1995).

Empirical research has documented some growth in central bank independence since the 1980s. At the same time, in developed countries this process was more accelerated, likely due to their transition to inflation targeting policy, which cannot be implemented under a controlled central bank. Empirical research has identified some significant effects of increased central bank independence. First, it leads to a decrease in the level of inflation as well as its volatility (Garriga \& Rodriguez, 2020; Klomp \& De Haan, 2010). Second, a more independent central bank is associated with less volatile economic growth and less uncertainty among economic agents (Garriga, 2016). In addition, Papadamou, Sidiropoulos, \& Spyromitros (2017) found a positive relationship between central bank independence and financial market volatility, identifying the need for increased transparency in monetary policy to reduce this effect.

Several of the most famous indices of central bank independence can be found in economic studies. In general, the assessment of regulator independence in each of these indices is based on an analysis of central bank responsibilities in national constitutions and central bank laws. Such indices are presented in studies by Alesina (1989); Cukierman, Web, \& Neyapti (1992) and Cukierman (1992), and assess the formal, or de jure, independence of the central bank, which may differ from the real state of affairs. In this regard, Almeida, Fry, \& Goodhart (1996) and Blinder (2000) assessed central bank independence based on survey results. Their disadvantages were their narrower coverage both by country and by aspects of central bank responsibilities, as well as low comparability of estimates (Garriga, 2016). Formal indices of independence do not have these drawbacks, thus making them suitable for statistical analysis.

In the previous section, it was noted that the quality of institutions plays a significant role in attracting FDI. Economic studies highlight the role of the rule of law, control over corruption, and political stability; however, central bank independence has not currently been considered a potential determinant of FDI inflows. This article aims to fill this gap. It is reasonable to assume that, with a higher independence of the central bank, the economy 
faces lower and more stable inflation, and trust in the monetary authorities and the structure of macroeconomic policy in general increases. This should logically contribute to the growth of the investment attractiveness of the economy, expressed by a more significant inflow of FDI.

\section{DATA AND ECONOMETRIC FRAMEWORK}

This study focuses on the relationship between central bank independence and FDI inflows into the economy. Linear panel regressions with the inflow of FDI as a dependent variable became the primary method of empirical analysis. The list of explanatory variables covers indicators influencing the inflow of FDI, which were discussed in Section 1. Equation 1 describes the specification of the model estimated by the ordinary least squares (OLS) method, while Equations 2 and 3 are panel regressions with fixed and random effects, respectively. Thus, the basic regression equations are as follows:

$$
\begin{aligned}
& F D I=\beta_{1} C B I_{i t}+\beta_{2} X_{i t}+\alpha+\varepsilon_{i t}, \\
& F D I=\beta_{1} C B I_{i t}+\beta_{2} X_{i t}+\alpha_{i}+\varepsilon_{i t}, \\
& F D I=\beta_{l} C B I_{i t}+\beta_{2} X_{i t}+\alpha+u_{i t}+\varepsilon_{i t},
\end{aligned}
$$

where $F D I_{i t}$ is the inflow of FDI into the country $i$ in year $t$ measured by either the percentage of real GDP or the nominal value in billions of USD. $C B I_{i t}$ is the index of independence of the central bank of the country $i$ in year $t$. $X_{i t}$ is a vector of independent variables affecting the inflow of FDI into the economy, including the annual growth rate of the country's real GDP; the size of the economy proxied by GDP in current prices; inflation; the real interest rate; the level of trade openness of the economy; the government's budget balance; the level of government debt; the size of the current account of the balance of payments; and the level of human capital development. In addition, to test the robustness of the results, variables that characterize the institutional environment of the economy were included in the model - control over corruption; government effectiveness; quality of regulation; and the rule of law. Moreover, country-specific fixed effects $\left(\alpha_{i}\right)$ were included in the Equation 2, and $u_{i t}$ in Equation 3 reflects betweenentity error. Finally, $\varepsilon_{i t}$ is an unobserved error term varying across time and countries.

Table 1. Description of Data

\begin{tabular}{l|l|l}
\hline Variable & Description & Source \\
\hline FDI_GDP & Foreign direct investment inwards $\%$ of GDP) & WDI \\
\hline FDI_NOM & Foreign direct investment inwards $(\$$ bln $)$ & WDI \\
\hline CBI & Central bank independence & Garriga (2016) \\
\hline GROWTH & Real GDP growth rate $\%$ annually) & WDI \\
\hline GDP & GDP at current prices $\$$ bln $)$ & WDI \\
\hline INFLATION & Consumer price index $\%$ annually) & WDI \\
\hline OPENNESS & $\begin{array}{l}\text { Trade openness measured as the sum of a } \\
\text { country's exports and imports } \% \text { of GDP). }\end{array}$ & $\begin{array}{l}\text { Author's calculations based on } \\
\text { WDI data }\end{array}$ \\
\hline RIR & $\begin{array}{l}\text { Real interest rate measured as the deposit } \\
\text { interest rate adjusted to inflation rate (\% } \\
\text { annually) }\end{array}$ & $\begin{array}{l}\text { Author's calculations based on } \\
\text { WDI data }\end{array}$ \\
\hline FISCAL_BALANCE & $\begin{array}{l}\text { General government net lending/borrowing (\% } \\
\text { of GDP) }\end{array}$ & WEO \\
\hline DEBT & General government gross debt $\%$ of GDP) & WEO \\
\hline CAB & Current account balance $\%$ of GDP) & WEO \\
\hline GROSS_CAP_FORM & Gross capital formation $\%$ of GDP) & WDI \\
\hline HDI & Human development index & UNDP \\
\hline CONT_CORR & Control of corruption & WGI \\
\hline GOVERNMENT_EFF & Government effectiveness & WGI \\
\hline REG_QUALITY & Regulatory quality & WGI \\
\hline RULE_LAW & Rule of law &
\end{tabular}

Most of the indicators were extracted from the World Bank's World Development Indicators (WDI) database, the World Economic Outlook (WEO) database of the International Monetary Fund and the World Bank's 
Worldwide Governance Indicators (WGI) database. To measure the level of human capital development, the corresponding index of the United Nations Development Program (UNDP) was used. Table 1 provides details of the variables used.

The study collected data for 180 countries for the period from 1970 to 2012. Such time frames are limited, first, by the availability of macroeconomic data, with the data being available only since 1970 for most countries of the world. Second, data on the central bank independence index are available only up to 2012 (it should be noted that the index from Garriga (2016) covers the longest period of time among all such indicators). Table 2 lists the descriptive statistics for the variables used.

Table 2. Descriptive Statistics of Variables.

\begin{tabular}{l|c|c|c|c|c}
\hline Variable & Obs. & Mean & Std. Dev. & Min. & Max. \\
\hline FDI_GDP & 6288 & 3.375 & 12.121 & -58.322 & 451.639 \\
\hline FDI_NOM & 6694 & 3.775 & 21.455 & -29.679 & 733.826 \\
\hline CBI & 5756 & 0.476 & 0.190 & 0.016 & 0.979 \\
\hline GROWTH & 6423 & 3.869 & 6.541 & -64.047 & 149.973 \\
\hline GDP & 6581 & 173.065 & 820.748 & 0.016 & 16197.01 \\
\hline INFLATION & 5661 & 29.965 & 394.398 & -60.496 & 23773.13 \\
\hline OPENNESS & 5978 & 74.850 & 46.502 & 0.167 & 437.326 \\
\hline RIR & 2849 & -1.746 & 216.849 & -5042.101 & 6446.56 \\
\hline FISCAL_BALANCE & 3800 & -2.927 & 16.877 & -557.499 & 125.135 \\
\hline DEBT & 3170 & 58.808 & 47.645 & 0 & 514.916 \\
\hline CAB & 5046 & -2.707 & 11.409 & -242.188 & 106.836 \\
\hline GROSS_CAP_FORM & 5699 & 23.511 & 8.526 & -13.405 & 89.381 \\
\hline HDI & 3685 & 0.644 & 0.167 & 0.192 & 0.944 \\
\hline CONT_CORR & 3020 & -0.077 & 0.993 & -1.868 & 2.469 \\
\hline GOVERNMENT_EFF & 3012 & -0.066 & 0.968 & -2.402 & 2.436 \\
\hline REG_QUALITY & 3012 & -0.068 & 0.965 & -2.645 & 2.230 \\
\hline RULE_LAW & 3036 & -0.107 & 0.989 & -2.606 & 2.013 \\
\hline
\end{tabular}

\section{EMPIRICAL ANALYSIS}

At the first stage of econometric modelling, a benchmark model was evaluated based on full-sample panel data for each economy. Table 3 presents the results of the baseline model, which includes the highlighted factors that affect the inflow of FDI into the economy, except for central bank independence (CBI). This step is necessary for the subsequent comparison of the regression coefficients after the inclusion of CBI to ensure that results are adequate. The study used a pooled linear regression (OLS) and a linear panel regression with fixed effects (FE) and random effects (RE). To ensure that the results of the analysis are not distorted by the possible problem of heteroscedasticity, hereinafter in the tables, robust standard errors are reported in parentheses.

Table 4 shows the results of the econometric analysis after including the central bank independence index in the model. In the OLS and FE regressions, this variable has a statistically significant positive effect on the inflow of FDI into the economy, increasing it by 2.6 and 5.9 percentage points, respectively. The results of the analysis are consistent not only with the findings of previous studies but also with economic logic. In particular, some models indicate that the inflow of FDI into the economy increases with the rise in human development index (HDI) and the trade openness of the economy. At the same time, an increase in public debt leads to a decrease in the inflow of FDI.

At the second stage of the empirical analysis, three panel regressions (OLS, FE and RE) were compared against each other to select the model that best describes the data. The Breusch-Pagan Lagrange multiplier (LM) test (Breusch \& Pagan, 1980) showed that a random effects model is preferable to linear pooled regression. The F-test demonstrated that the random effects model described data better than linear pooled regression. Finally, the Hausman test (Hausman, 1978) revealed that panel regression with fixed effects is preferable to the model with random effects. It should be noted that models with standard errors were used to perform the indicated tests. Table 5 summarizes the results of the tests. 
Table 3. Baseline Model: Determinants of FDI Inflows (without CBI)

Period: 1970-2012

Dependent variable - FDI inflows (as a share of GDP)

\begin{tabular}{|c|c|c|c|}
\hline & $(1)$ & $(2)$ & (3) \\
\hline VARIABLE & OLS & FE & RE \\
\hline \multirow[t]{2}{*}{ GROWTH } & 0.109 & 0.0529 & 0.0523 \\
\hline & $(0.0721)$ & $(0.0475)$ & $(0.0611)$ \\
\hline \multirow[t]{2}{*}{ GDP } & $0.000496^{*}$ & 0.000162 & 0.000387 \\
\hline & $(0.000283)$ & $(0.000595)$ & $(0.000428)$ \\
\hline \multirow[t]{2}{*}{ INFLATION } & -0.0260 & 0.0356 & -0.00896 \\
\hline & $(0.0257)$ & $(0.0424)$ & $(0.0396)$ \\
\hline \multirow[t]{2}{*}{ OPENNESS } & $0.0546^{* * * * *}$ & 0.0175 & 0.0465 **** \\
\hline & $(0.00630)$ & $(0.0404)$ & $(0.0119)$ \\
\hline \multirow[t]{2}{*}{ RIR } & -0.0413 & -0.0120 & -0.0439 \\
\hline & $(0.0376)$ & $(0.0535)$ & $(0.0534)$ \\
\hline \multirow[t]{2}{*}{ FISCAL_BALANCE } & $0.228^{*} * * *$ & $0.0997^{*}$ & $0.144^{* * * *}$ \\
\hline & $(0.0454)$ & (0.0529) & $(0.0441)$ \\
\hline \multirow[t]{2}{*}{ DEBT } & -0.00607 & $-0.0530^{*}$ & $-0.0353^{*}$ \\
\hline & $(0.0113)$ & $(0.0306)$ & $(0.0195)$ \\
\hline \multirow[t]{2}{*}{$\mathrm{CAB}$} & $-0.344^{*} * * *$ & -0.264 **** & -0.317 ***** \\
\hline & $(0.0406)$ & $(0.0675)$ & $(0.0591)$ \\
\hline \multirow[t]{2}{*}{ GROSS_CAP_FORM } & -0.0416 & 0.0754 & 0.00591 \\
\hline & $(0.0429)$ & $(0.0727)$ & $(0.0640)$ \\
\hline \multirow[t]{2}{*}{ HDI } & 4.434**** & 9.607 & 3.781 \\
\hline & $(1.429)$ & $(9.883)$ & $(2.902)$ \\
\hline \multirow[t]{2}{*}{ Constant } & -2.294 & -3.074 & -0.721 \\
\hline & $(1.558)$ & $(8.249)$ & $(4.632)$ \\
\hline Observations & 1493 & 1493 & 1493 \\
\hline R-squared & 0.245 & 0.194 & 0.178 \\
\hline
\end{tabular}

Table 4. Baseline Model: Determinants of FDI Inflows (including CBI).

Period: 1970-2012

Dependent variable - FDI inflows (as a share of GDP

\begin{tabular}{|c|c|c|c|}
\hline & (1) & (2) & (3) \\
\hline VARIABLE & OLS & FE & RE \\
\hline \multirow[t]{2}{*}{ CBI } & $2.592^{*}$ *** & $5.946^{*}$ & 3.112 \\
\hline & $(1.003)$ & $(3.225)$ & $(2.079)$ \\
\hline \multirow[t]{2}{*}{ GROWTH } & 0.116 & 0.0575 & 0.0577 \\
\hline & $(0.0744)$ & (0.0490) & $(0.0622)$ \\
\hline \multirow[t]{2}{*}{ GDP } & $0.000496^{*}$ & 0.000166 & 0.000365 \\
\hline & (0.000293) & $(0.000583)$ & $(0.000440)$ \\
\hline \multirow[t]{2}{*}{ INFLATION } & $-0.0467 *$ & 0.0193 & -0.0231 \\
\hline & $(0.0243)$ & $(0.0438)$ & (0.0391) \\
\hline \multirow[t]{2}{*}{ OPENNESS } & 0.0554 **** & 0.0105 & $0.0452^{* * * * *}$ \\
\hline & (0.00669) & $(0.0404)$ & $(0.0121)$ \\
\hline \multirow[t]{2}{*}{ RIR } & -0.0297 & -0.00691 & -0.0288 \\
\hline & (0.0389) & (0.0592) & (0.0572) \\
\hline \multirow[t]{2}{*}{ FISCAL_BALANCE } & 0.228****** & 0.109** & $0.148 * * *$ \\
\hline & (0.0461) & (0.0530) & $(0.0443)$ \\
\hline \multirow[t]{2}{*}{ DEBT } & -0.00470 & $-0.0523^{*}$ & $-0.0345^{*}$ \\
\hline & (0.0120) & (0.0309) & $(0.0205)$ \\
\hline \multirow[t]{2}{*}{ CAB } & $-0.336^{* * * * *}$ & $-0.268^{*} * *$ & $-0.316^{* * * *}$ \\
\hline & $(0.0427)$ & $(0.0729)$ & $(0.0622)$ \\
\hline \multirow[t]{2}{*}{ GROSS_CAP_FORM } & -0.0288 & 0.0867 & 0.0164 \\
\hline & $(0.0467)$ & (0.0763) & $(0.0671)$ \\
\hline \multirow[t]{2}{*}{ HDI } & 4.175 **** & 5.162 & 3.437 \\
\hline & $(1.386)$ & $(10.01)$ & $(2.646)$ \\
\hline \multirow[t]{2}{*}{ Constant } & $-3.881 * *$ & -3.062 & -2.356 \\
\hline & $(1.915)$ & $(8.157)$ & $(5.172)$ \\
\hline Observations & 1444 & 1444 & 1444 \\
\hline R-squared & 0.253 & 0.207 & 0.189 \\
\hline
\end{tabular}


Table 5. Model Comparison Test Results (1970-2012).

\begin{tabular}{c|c|c|c}
\hline \multicolumn{2}{c}{ Breusch-Pagan LM test } & F-test & Hausman test \\
\hline Compared models & OLS and RE & OLS and FE & RE and FE \\
\hline Null hypothesis & $\begin{array}{c}\text { All variances across } \\
\text { entities are equal to } 0\end{array}$ & $\begin{array}{c}\text { All within-entity errors } \\
\text { are equal to zero }\end{array}$ & $\begin{array}{c}\text { The difference in the } \\
\text { coefficients of FE and RE } \\
\text { models is not systematic }\end{array}$ \\
\hline Test statistics & $527.54^{* * * *} *{ }^{* * *} \mathrm{p}<0.01,{ }^{* *} \mathrm{p}<0.05,{ }^{*} \mathrm{p}<0.1$. & $6.67^{* * *}$ & $111.32^{* * *}$ \\
\hline
\end{tabular}

Table 6. Model Comparison Test Results (1996-2012).

\begin{tabular}{|c|c|c|c|}
\hline & Breusch-Pagan LM test & F-test & Hausman test \\
\hline Compared models & OLS and RE & OLS and FE & $\mathrm{RE}$ and $\mathrm{FE}$ \\
\hline Null hypothesis & $\begin{array}{c}\text { All variances across } \\
\text { entities are equal to zero }\end{array}$ & $\begin{array}{l}\text { All country-specific fixed } \\
\text { effects are equal to zero }\end{array}$ & $\begin{array}{l}\text { The difference in the } \\
\text { coefficients of } \mathrm{FE} \text { and } \mathrm{RE} \\
\text { models is not systematic }\end{array}$ \\
\hline Test statistics & $552.94 * * *$ & $7.03^{* * *} *$ & $129.72^{* * * *}$ \\
\hline
\end{tabular}

Table 7. Effect of Institutions.

\begin{tabular}{|c|c|c|c|c|c|}
\hline \multicolumn{6}{|c|}{ Period: $1996-2012$} \\
\hline \multicolumn{6}{|c|}{ Dependent variable - FDI inflows (as a share of GDP) } \\
\hline VARIABLE & (1) & $(2)$ & (3) & $(4)$ & $(5)$ \\
\hline \multirow[t]{2}{*}{ CBI } & $5.163^{*}$ & $4.479^{*}$ & $4.454^{*}$ & $4.773^{*}$ & $4.395^{*}$ \\
\hline & $(2.977)$ & $(2.648)$ & $(2.652)$ & $(2.643)$ & $(2.670)$ \\
\hline \multirow[t]{2}{*}{ GROWTH } & 0.0523 & 0.0563 & 0.0562 & 0.0569 & 0.0568 \\
\hline & $(0.0569)$ & $(0.0578)$ & $(0.0582)$ & $(0.0587)$ & $(0.0582)$ \\
\hline \multirow[t]{2}{*}{ GDP } & 0.000108 & 0.000205 & 0.000197 & 0.000170 & 0.000177 \\
\hline & $(0.000475)$ & $(0.000465)$ & $(0.000476)$ & $(0.000463)$ & $(0.000470)$ \\
\hline \multirow[t]{2}{*}{ INFLATION } & 0.0393 & 0.0411 & 0.0388 & 0.0360 & 0.0385 \\
\hline & $(0.0401)$ & $(0.0397)$ & $(0.0417)$ & $(0.0411)$ & $(0.0404)$ \\
\hline \multirow[t]{2}{*}{ OPENNESS } & 0.00319 & 0.00390 & 0.00411 & 0.00292 & 0.00417 \\
\hline & $(0.0406)$ & $(0.0413)$ & $(0.0412)$ & $(0.0424)$ & $(0.0413)$ \\
\hline \multirow[t]{2}{*}{ RIR } & -0.00539 & -0.0120 & -0.0144 & -0.0222 & -0.0173 \\
\hline & $(0.0562)$ & $(0.0573)$ & $(0.0622)$ & $(0.0583)$ & $(0.0603)$ \\
\hline \multirow[t]{2}{*}{ FISCAL_BALANCE } & $0.0892^{*}$ & $0.0786^{*}$ & $0.0786^{*}$ & $0.0799^{*}$ & $0.0775^{*}$ \\
\hline & $(0.0461)$ & $(0.0442)$ & $(0.0443)$ & $(0.0437)$ & $(0.0439)$ \\
\hline \multirow[t]{2}{*}{ DEBT } & $-0.0627^{* *}$ & $-0.0655^{* * *}$ & $-0.0659^{* *}$ & $-0.0649^{* * *}$ & $-0.0655^{* * *}$ \\
\hline & $(0.0299)$ & $(0.0288)$ & $(0.0287)$ & $(0.0277)$ & $(0.0284)$ \\
\hline \multirow[t]{2}{*}{$\mathrm{CAB}$} & $-0.295 * * *$ & $-0.303^{* * *}$ & $-0.304 * * *$ & $-0.299^{* * * *}$ & $-0.302 * * *$ \\
\hline & $(0.0664)$ & $(0.0626)$ & $(0.0596)$ & $(0.0594)$ & $(0.0605)$ \\
\hline \multirow[t]{2}{*}{ GROSS_CAP_FORM } & 0.0823 & 0.0825 & 0.0817 & 0.0886 & 0.0846 \\
\hline & $(0.0793)$ & $(0.0787)$ & $(0.0787)$ & $(0.0762)$ & $(0.0785)$ \\
\hline \multirow[t]{2}{*}{ HDI } & 2.281 & -1.319 & -1.503 & -3.184 & -2.022 \\
\hline & $(10.34)$ & $(10.41)$ & $(11.38)$ & $(10.94)$ & $(11.05)$ \\
\hline \multirow[t]{2}{*}{ CONT_CORR } & & 0.500 & & & \\
\hline & & $(0.953)$ & & & \\
\hline \multirow[t]{2}{*}{ GOVERNMENT_EFF } & & & 0.312 & & \\
\hline & & & $(1.906)$ & & \\
\hline \multirow[t]{2}{*}{ RULE_LAW } & & & & $2.516^{* * *}$ & \\
\hline & & & & $(1.257)$ & \\
\hline \multirow[t]{2}{*}{ REG_QUALITY } & & & & & 0.796 \\
\hline & & & & & $(1.291)$ \\
\hline \multirow[t]{2}{*}{ Constant } & 0.435 & 3.272 & 3.395 & 4.633 & 3.673 \\
\hline & $(8.329)$ & $(8.197)$ & $(9.031)$ & $(8.315)$ & $(8.702)$ \\
\hline Observations & 1,363 & 1,335 & 1,335 & 1,335 & 1,335 \\
\hline R-squared & 0.229 & 0.236 & 0.236 & 0.239 & 0.237 \\
\hline
\end{tabular}


At the third stage, linear panel regressions were employed, which included variables indicating the quality of institutions. Since data on the quality of institutions are only available from 1996, the OLS, FE and RE models were first employed using data from 1996 to 2012. Further, these models were compared with each other according to the scheme described above using the Breusch-Pagan LM test, the F-test and the Hausman test. The results are presented in Table 6. As in the previous case, the FE model describes data better than other models, therefore it is used as a benchmark model.

Column 1 of Table 7 presents the results of the benchmark model (see column 2 of Table 4) estimated on data from 1996 to 2012. Columns 2-5 present econometric modelling results when different institutional variables are included. In all cases, the coefficient of the central bank independence index remained statistically significant, indicating a positive impact of this indicator on the inflow of FDI into the economy. Depending on the model specification, an increase in CBI index by one point leads to an increase in FDI inflows by 4.4-5.2 percentage points. At the same time, the signs and statistical significance of the coefficients for government debt, fiscal balance and current account balance have also remained unchanged in comparison with the results presented in Table 4. Also, the results of the analysis demonstrate that the strengthening of the rule of law in the country statistically significantly increases the inflow of FDI by 2.5 percentage points.

Table 8. Robustness Check: Alternative Measurement of FDI Inflows

\begin{tabular}{|c|c|c|c|c|}
\hline \multicolumn{5}{|l|}{ Period: $1996-2012$} \\
\hline \multicolumn{5}{|c|}{ Dependent variable - FDI inflows (in billions of US dollar) } \\
\hline VARIABLE & $(1)$ & $(2)$ & (3) & $(4)$ \\
\hline \multirow[t]{2}{*}{$\mathrm{CBI}$} & $22.20^{* * * *}$ & $16.03^{*}$ & $16.05^{* *}$ & $15.56^{*}$ \\
\hline & $(8.042)$ & $(8.174)$ & $(8.150)$ & $(8.133)$ \\
\hline \multirow[t]{2}{*}{ GROWTH } & 0.0795 & 0.0986 & 0.0981 & 0.116 \\
\hline & $(0.167)$ & $(0.166)$ & $(0.166)$ & $(0.166)$ \\
\hline \multirow[t]{2}{*}{ GDP } & $0.0309^{* * * *}$ & $0.0307 * * *$ & $0.0309 * * *$ & $0.0309^{* * * *}$ \\
\hline & $(0.00210)$ & $(0.00211)$ & $(0.00211)$ & $(0.00210)$ \\
\hline \multirow[t]{2}{*}{ INFLATION } & 0.232 & 0.222 & 0.233 & 0.252 \\
\hline & $(0.191)$ & $(0.192)$ & $(0.192)$ & $(0.192)$ \\
\hline \multirow[t]{2}{*}{ OPENNESS } & $0.0786^{*}$ & $0.0782^{*}$ & $0.0787^{*}$ & $0.0772^{*}$ \\
\hline & $(0.0458)$ & $(0.0463)$ & $(0.0462)$ & $(0.0461)$ \\
\hline \multirow[t]{2}{*}{ RIR } & 0.283 & 0.285 & 0.327 & 0.348 \\
\hline & $(0.226)$ & $(0.228)$ & $(0.228)$ & $(0.227)$ \\
\hline \multirow[t]{2}{*}{ FISCAL_BALANCE } & 0.127 & 0.0864 & 0.0961 & 0.102 \\
\hline & $(0.171)$ & $(0.175)$ & $(0.175)$ & $(0.175)$ \\
\hline \multirow[t]{2}{*}{ DEBT } & -0.0209 & -0.0213 & -0.0249 & -0.0210 \\
\hline & $(0.0262)$ & $(0.0266)$ & $(0.0266)$ & $(0.0265)$ \\
\hline \multirow[t]{2}{*}{ CAB } & 0.0602 & 0.0882 & 0.0562 & 0.0487 \\
\hline & (0.130) & (0.132) & $(0.132)$ & (0.132) \\
\hline \multirow[t]{2}{*}{ GROSS_CAP_FORM } & 0.0189 & 0.0490 & 0.0141 & 0.0141 \\
\hline & $(0.171)$ & $(0.173)$ & $(0.173)$ & $(0.173)$ \\
\hline \multirow[t]{2}{*}{ HDI } & 22.37 & 22.18 & 31.23 & 39.08 \\
\hline & $(31.59)$ & $(32.23)$ & $(32.26)$ & $(32.44)$ \\
\hline \multirow[t]{2}{*}{ RULE_LAW } & & 2.921 & & \\
\hline & & $(4.498)$ & & \\
\hline \multirow[t]{2}{*}{ REG_QUALITY } & & & -5.668 & \\
\hline & & & $(3.628)$ & \\
\hline \multirow[t]{2}{*}{ GOVERNMENT_EFF } & & & & $-10.96 * *$ \\
\hline & & & & $(4.348)$ \\
\hline \multirow[t]{2}{*}{ Constant } & $-35.66^{*}$ & -32.05 & $-37.81^{*}$ & $-43.77 * *$ \\
\hline & $(19.99)$ & $(20.38)$ & $(20.35)$ & $(20.54)$ \\
\hline Observations & 1363 & 1335 & 1335 & 1335 \\
\hline R-squared & 0.188 & 0.188 & 0.189 & 0.192 \\
\hline
\end{tabular}


In order to assess the robustness of the results obtained, linear panel regressions with fixed effects were employed, where the nominal volume of incoming FDI in billions of US dollars serves as a dependent variable. Because the model included institutional variables, it was estimated using data from 1996 to 2012. The results are presented in Table 8; the coefficient of the central bank independence index remained positive and statistically significant, as did the GDP at current prices and the country's level of trade openness. Depending on the model specification, a one-point increase in the CBI index leads to additional FDI inflows of 15.6-22.2 billion US dollars.

The econometric analysis that was conducted allows us to conclude that the independence of the central bank has a positive effect on the inflow of FDI into the economy. The results were tested for robustness by incorporating institutional characteristics into the model as well as an alternative measurement of FDI inflows.

\section{CONCLUSION}

This study demonstrated a positive relationship between central bank independence and FDI inflows. This finding complements the list of statistically significant determinants of FDI inflows, for which recent economic studies include a wide range of institutional variables.

Furthermore, it is necessary to identify several of the most probable channels of influence of the independence of the central bank on the inflow of FDI. First, a more independent central bank provides lower and more stable inflation. Strengthening macroeconomic stability boosts investor confidence and encourages investment flows. Second, the increased independence of the central bank is associated with an increase in the level of financial development, expressed through an increase in both long-term lending and access to financial services. This helps to increase the potential of the economy, thus enhancing its investment attractiveness.

The formulated hypotheses can potentially become the subject of further research on this topic. At the same time, the results obtained outline the direction of potential reforms, particularly in developing countries. The increased independence of the central bank, together with other institutional changes, will improve the country's investment climate, contributing to the acceleration of economic growth.

Funding: This study received no specific financial support.

Competing Interests: The author declares that there are no conflicts of interests regarding the publication of this paper.

\section{REFERENCES}

Alesina, A. (1989). Politics and business cycles in industrial democracies. Economic Policy, 4(8),55-98.Available at: https://doi.org/10.2307/1344464.

Ali, F. A., Fiess, N., \& MacDonald, R. (2010). Do institutions matter for foreign direct investment? Open Economies Revierw 21(2),201-2 19.Available at: http://dx.doi.org/10.1007/s11079-010-9170-4.

Almeida, A., Fry, M. J., \& Goodhart, C. (1996). Central banking in developing countries: Objectives, activities and independence. New York: Routledge.

Bevan, A. A., \& Estrin, S. (2004). The determinants of foreign direct investment into European transition economies. Journal of Comparative Economics, 32(4),775-787.Available at: http://dx.doi.org/10.1016/j.jce.2004.08.006.

Blinder, A. S. (2000). Central-bank credibility: Why do we care? How do we build it? American Economic Revierw, 90(5),14211431.Available at: http://dx.doi.org/10.1257/aer.90.5.1421.

Blonigen, B. A. (2005). A review of the empirical literature on FDI determinants. Atlantic Economic Journal, 33(4),383-403.

Breusch, T., \& Pagan, A. (1980). The lagrange multiplier test and its applications for the error components model with incomplete panels. Review of Economic Studies, 47(1),239-253.Available at: http://dx.doi.org/10.2307/2297111.

Cukierman, A. (1992). Central bank strategy, credibility, and independence: Theory and evidence. Cambridge: MIT Press.

Cukierman, A., Web, S. B., \& Neyapti, B. (1992). Measuring the independence of central banks and its effect on policy outcomes. The World Bank Economic Review, 6(3),353-398.Available at: http://dx.doi.org/10.1093/wber/6.3.353. 
Fischer, S. (1995). Central-bank independence revisited. American Economic Revierw, 85(2),201-206.

Garriga, A. C. (2016). Central bank independence in the world: A new data set. International Interactions, 42(5),849-868.Available at: http://dx.doi.org/10.1080/03050629.2016.1188813.

Garriga, A. C., \& Rodriguez, C. M. (2020). More effective than we thought: Central bank independence and inflation in developing countries. Economic Modelling, 85,87-105.Available at: http://dx.doi.org/10.1016/j.econmod.2019.05.009.

Hausman, J. A. (1978). Specification tests in econometrics. Econometrica: Journal of the Econometric Society, 46(6),12511271.Available at: http://dx.doi.org/10.2307/1913827.

Iamsiraroj, S. (2016). The foreign direct investment-economic growth nexus. International Review of Economics $\mathcal{F}^{\circ}$ Finance, 42,1 16-133.Available at: http://dx.doi.org/10.1016/j.iref.2015.10.044.

Kaur, M., Yadav, S. S., \& Gautam, V. (2012). Foreign direct investment and current account deficit-a causality analysis in context of India. Journal of International Business and Economy, 13(2),85-106.

Kinuthia, B. K., \& Murshed, S. M. (2015). FDI determinants: Kenya and Malaysia compared. Journal of Policy Modeling, 37(2),388-400.Available at: http://dx.doi.org/10.1016/j.jpolmod.2015.01.013.

Klomp, J., \& De Haan, J. (2010). Inflation and central bank independence: A meta-regression analysis. Journal of Economic Surveys, 24(4),593-62 1.Available at: http://dx.doi.org/10.1111/j.1467-6419.2009.00597.x

Kok, R., \& Ersoy, B. A. (2009). FDI impacts on industrial agglomeration: the case of Java, Indonesia. Journal of Asia Business Studies, 36(1/2),105-123.Available at: http://dx.doi.org/10.1108/03068290910921226.

Mohanty, S. P., \& Behera, S. R. (2017). Macroeconomic determinants of FDI inflows to India: An empirical estimation. Journal of International Economics, 8(2),43-61.

Papadamou, S., Sidiropoulos, M., \& Spyromitros, E. (2017). Does central bank independence affect stock market volatility? Research in International Business and Finance, 42,855-864.Available at: http://dx.doi.org/10.1016/j.ribaf.2017.07.021.

Pegkas, P. (2015). The impact of FDI on economic growth in Eurozone countries. The Journal of Economic Asymmetries, 12(2),124-132.Available at: http://dx.doi.org/10.1016/j.jeca.2015.05.001.

Rogoff, K., \& Reinhart, C. M. (2003). FDI to Africa: The role of price stability and currency instability: IMF Working Paper.

Sayek, S. (2009). Foreign direct investment and inflation. Southern Economic Journal, 76(2),419-443.Available at: http://dx.doi.org/10.4284/sej.2009.76.2.419.

Vijayakumar, N., Sridharan, P., \& Rao, K. C. S. (2010). Determinants of FDI in BRICS Countries: A panel analysis. International Journal of Business Science \& Applied Management (IJBSAM), 5(3),1-13.

Yao, S., \& Zhang, Z. (2001). On regional inequality and diverging clubs: A case study of contemporary China. Journal of Comparative Economics, 29(3),466-484.Available at: http://dx.doi.org/10.1016/j.jce.2006.10.007. answerable for any loss, damage or liability etc. caused in relation to/arising out of the use of the content. 